\title{
Seasonality in recreation supply and demand in an urban lake ecosystem in Finland
}

\author{
Kati Vierikko ${ }^{1} \cdot$ Vesa Yli-Pelkonen ${ }^{2}$
}

Published online: 29 March 2019

(C) The Author(s) 2019

\begin{abstract}
Monetary valuation methods are commonly used to analyze recreation values of water ecosystems. However, most studies on water-related recreation values have not analyzed direct links between ecological elements providing recreation opportunities and user demands. Therefore, we implemented an ecosystem service approach to study human-nature interaction during the actual recreation visit to an urban freshwater site. We developed a conceptual model of local cultural ecosystem services (CES) to study interactions between recreation supply and demand. We were interested in seasonality of water-related recreation supply, and the different demands of summer and off-summer visitors. We chose urban Lake Kuusijärvi in the city of Vantaa, Finland, as our case study area, because it is a popular outdoor recreation area around the year. We identified 14 key elements of the supply of local CES and 22 socio-cultural values for the demand for local CES. We found little seasonal change in recreation supply, but the socio-demographic characteristics and demands of summer and off-summer visitors varied significantly. Demand was higher and more diverse during the summer season, while off-summer visitors were more specific in their demands. Moreover, some visitors feared that some socio-cultural values can be lost if the recreational use of the lake area increases. We discuss our findings in a theoretical context focusing especially on interactions between supply and demand of local CES at Lake Kuusijärvi.
\end{abstract}

Keywords Cultural ecosystem services $\cdot$ Freshwater $\cdot$ Urban lake $\cdot$ Local scale $\cdot$ Recreational use

\section{Introduction}

Urban freshwater ecosystems (rivers, streams, lakes, ponds) and green areas surrounding them are important components of ecological and recreational network in cities (Sievänen and Neuvonen 2011) and can promote physical and mental well-being, regulate water-cycling, and support biological diversity (YliPelkonen et al. 2006; Völker and Kistemann 2013). Urban water ecosystems are often urban residents' favorite places to visit regularly to recover from stress (Korpela et al. 2010). Contributions of ecosystems, which arise from interactions between biotic and

Vesa Yli-Pelkonen

vesa.yli-pelkonen@helsinki.fi

Kati Vierikko

kati.vierikko@ymparisto.fi

1 Environmental Policy Centre, Finnish Environment Institute (SYKE), Latokartanonkaari 11, FI-00790 Helsinki, Finland

2 Ecosystems and Environment Research Programme, Faculty of Biological and Environmental Sciences, University of Helsinki, P.O. Box 65, FI-00014 University of Helsinki, Finland abiotic processes and which benefit society, are called ecosystem services (Haines-Young and Potschin 2010).

The concept of ecosystem services (ES) has become an important framework for understanding the links between ecosystem functions and human well-being (MEA (Millennium Ecosystem Assessment) 2005). Ecosystem services are commonly divided into three categories: provisioning, regulating and cultural (TEEB (The Economics of Ecosystems and Biodiversity) 2011; CICES 2017). Cultural ecosystem services (CES) are defined as "ecosystem's contribution to the non-material, such as recreation, aesthetic, educational and spiritual benefits for people that arise from human-ecosystem relationship" (Chan et al. 2011, p. 206). Research on CES, as well as other ES research, has focused especially on mapping and identifying spatial distribution, hotspots and coldspots of CES, by collecting data from local residents, community members and other stakeholders (e.g. Raymond et al. 2009; Plieninger et al. 2013; Rall et al. 2017).

Recreational use of nature areas (forests, water areas, protected areas) is one of the most commonly studied CES across research fields (e.g. Kakoyannis and Stankey 2002; Ormsby et al. 2004; Bell et al. 2009; Yli-Pelkonen 2013). 
Recreation ecology is a research field that has traditionally focused on recreational impact on vegetation or species abundance (e.g. Buckley 2005; Hamberg et al. 2010; D'Antonio et al. 2013). However, very few studies have analyzed the importance and value of single biophysical elements (supply) on recreational use or experiences (demand) (e.g. Hauru et al. 2014).

The recreation value and importance of water bodies have commonly been studied using monetary valuation approaches such as willingness to pay or travel cost method (Vesterinen et al. 2010; Gledhill and James 2012; Doherty et al. 2014; Curtis and Stanley 2016), but only a few studies have adopted non-monetary methods to analyze socio-cultural values of urban freshwater sites (e.g. Marttila 2007; Vierikko and Niemelä 2016). Preferences and values can vary greatly between individuals, and the study of the socio-cultural values will reveal how different individuals or user groups perceive recreation supplies (FelipeLucia et al. 2014). People's perceptions and preferences of nature areas are often studied using a quantitative research approach, such as structured questionnaires, GPS tracking or off-site GISbased mapping (e.g. Raymond et al. 2009; Bryan et al. 2010; D'Antonio et al. 2013; Plieninger et al. 2013; Laatikainen et al. 2015). Most of these studies addressing recreation demand (e.g. favorite places for recreation) have adopted a spatially broad (large nature areas, city-scale) approach, with little consideration of direct interaction between supply and demand (Scholte et al. 2015; D'Antonio et al. 2016).

Seasonal changes in the recreational use of nature areas with water bodies can be substantial (Kakoyannis and Stankey 2002). However, most on-site studies of recreational use or interaction between humans and nature in urban recreation areas (e.g. parks, watersides) are conducted in summer with little or no attention to how use and values of urban residents change temporally in such geographical regions, where weather conditions vary greatly over the year (e.g. Chiesura 2004; Dallimer et al. 2012; Dinnie et al. 2013; Voigt and Wurster 2015). For instance, in Finland, urban shores and beaches by lakes, rivers and the sea are frequently used for recreational purposes such as sunbathing, swimming or just sitting and relaxing during summer season. Swimming is, depending on the recreation site, often associated with sauna-going. In winter, when water bodies are ice-covered and shores and beaches snow-covered, there is a popular tradition of cutting off some square meters of ice near the shore, enabling a short dip or swim in the ice-cold water. Such iceswimming usually includes going to sauna before and after the swim, and is associated with health benefits (Laukkanen et al. 2018). Overall, changes in socio-cultural values (e.g. perceptions, experiences) can also affect the ecosystem contribution to the provision of CES, such as recreational experiences.

We studied seasonal changes in recreation supply and demand associated with an urban lake ecosystem and its surrounding environment, using a combined socioecological approach (D'Antonio et al. 2013). We developed a conceptual model for CES to precisely and comprehensively explore interactions between recreation supply and demand at a spatially accurate scale (Fig. 1). Firstly, we interpreted local supply, i.e. key biophysical and socio-physical elements, and their capacity to provide water-related CES. ${ }^{1}$ Secondly, we studied recreation demands by analyzing the socio-cultural values of individual visitors. We focus on assigned values, i.e. the relative importance of specific attributes for individuals at the site-level (Brown 1984, p. 233; McIntyre et al. 2008). We studied demand by exploring visitors' (i) motivations to arrive to the site and (ii) their experiences at the site. In addition, we measured (iii) the importance of key biophysical elements to the positive visiting experiences at the lake area. Furthermore, we compared whether there were differences between socio-demographic characteristics and sociocultural values of summer and off-summer visitors at the lake area. Besides biophysical and socio-physical supply, recreation areas have a specific socio-cultural environment that on the one hand can be managed and considered as a supply side (e.g. norms, regulations and rules), but on the other hand is influenced by visitors and their values (e.g. feeling of safety, inclusiveness, accessibility and positive and negative experiences) (Fig. 1). Finally, we will discuss linkages of recreation supply and demand to socio-cultural environment of the lake area.

\section{Material and methods}

We used a mixed-method research approach, which is appropriate when analyzing different data sources (quantitative and qualitative) together and making comprehensive analyses of interaction between ecological and social systems (MacKay and Campbell 2004). We adopted a qualitative research design for collecting and analyzing data, but used quantitative methods for presenting our results. We used an inductive approach for interpreting the results without a theory-driven explanation of the phenomenon (Goddard and Melville 2004). We present the methods in detail below.

\section{Recreation supply at Lake Kuusijärvi}

The study area is situated in the City of Vantaa, which belongs to the Helsinki Metropolitan Area in Finland (Fig. 2). The land area of the City of Vantaa is $238 \mathrm{~km}^{2}$ and it has 219,000 inhabitants with a population density of 920 inhabitants $/ \mathrm{km}^{2}$

\footnotetext{
${ }^{1}$ Water-related CES refer to leisure activities and experiences that are either directly provided by aquatic ecosystems (e.g. swimming, fishing, enjoying lake landscape) or supported by aquatic ecosystems (e.g. sun-bathing and walking along a shore).
} 


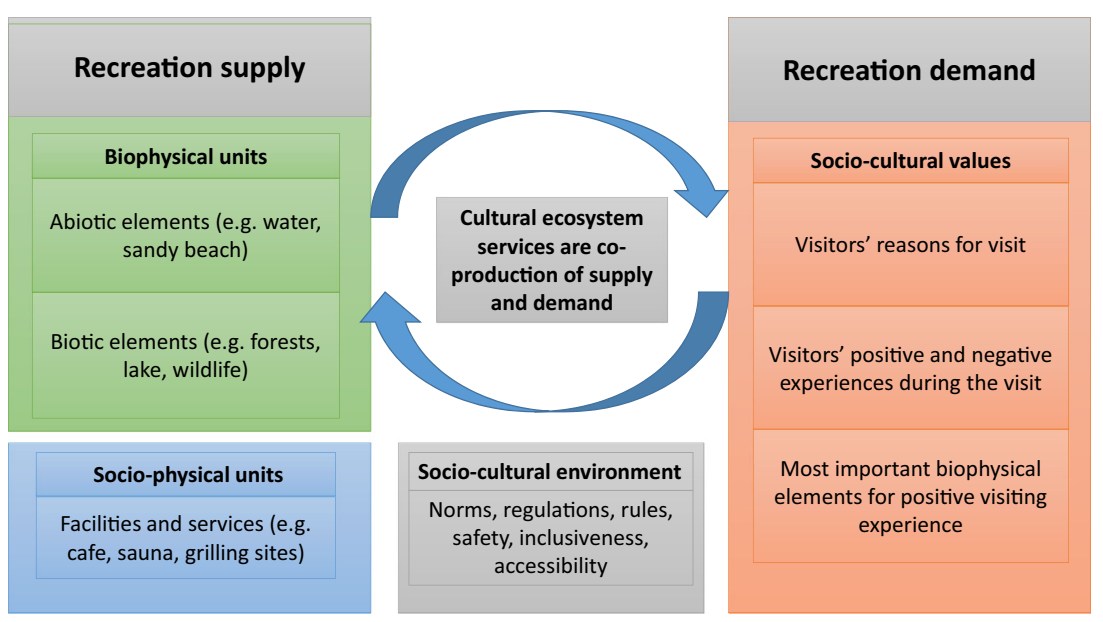

Fig. 1 A conceptual model for water-related cultural ecosystem services. The recreation supply includes biophysical and socio-physical units. The recreation demand includes reasons for visit and perceived experiences during the visit, as well as valuations of local biophysical elements. Local

land area (City of Vantaa 2017a). Lake Kuusijärvi (N $60^{\circ}$ $18.862^{\prime}$, E $25^{\circ} 6.715^{\prime}$ ), was chosen for this study, because, with its surroundings, it forms the Lake Kuusijärvi Outdoor Recreation Centre, a popular recreation area with about 350,000 visitors per year (Hellgren 2013). Lake Kuusijärvi is one of the two official public swimming sites (so-called European Union bathing water sites, which are large public beaches with more than 100 swimmers daily during the cultural ecosystem services are identified as a co-production of the socialecological system. Moreover, socio-cultural environment (in the middle) of the recreation site can have a strong influence on recreation

summer season) in the City of Vantaa. The beach area at Lake Kuusijärvi is well-managed with high-standard facilities, and has a separated swimming area $(<0.5 \mathrm{~m}$ deep) for small children. During the summer season two lifeguards are watching the swimming area $10 \mathrm{am}-8 \mathrm{pm}$ daily. As the beach area has been rather peaceful in general, there usually is no specific security personnel present at the site, except during some special events. In relation to the lake's size (7.54 ha) and
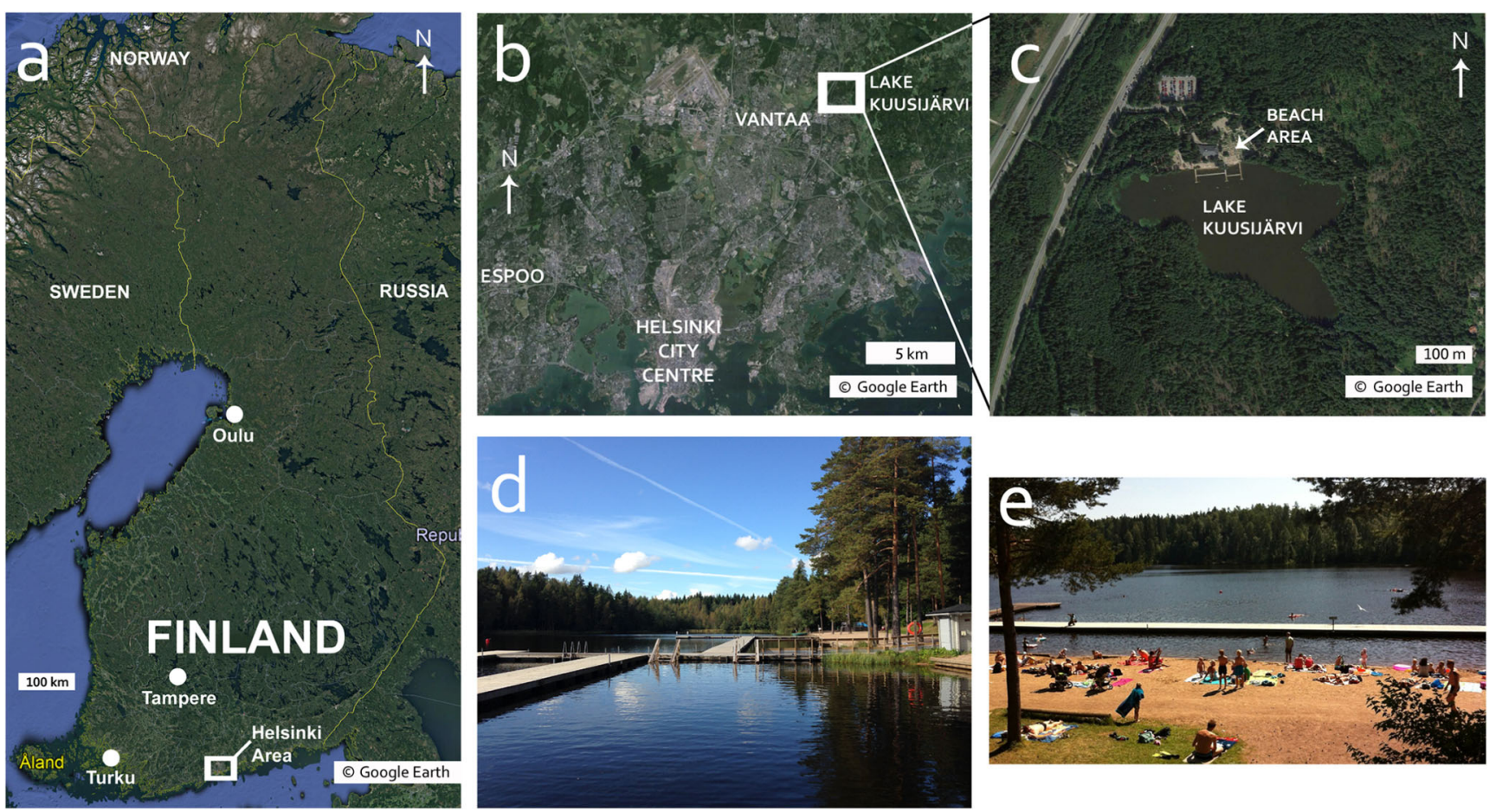

Fig. 2 Panel (a) presents the location of Helsinki Area in Finland, panel (b) shows the location of Lake Kuusijärvi in the Helsinki Area, as well as the locations of the cities of Vantaa, Espoo, and Helsinki, and panel (c) displays Lake Kuusijärvi and its surrounding forests, which together form the Lake Kuusijärvi Outdoor Recreation Centre. Panel (d) shows the swimming site in late autumn and panel (e) displays a part of the beach area in summer 
total shoreline $(1340 \mathrm{~m})$, the $150 \mathrm{~m}$ long beach is one of the most popular beaches in Finland, especially as it is situated in the vicinity of large urban residential areas (Särkelä et al. 2008). The lake is rather shallow (mean depth $1.7 \mathrm{~m}$, max. depth $2.5 \mathrm{~m}$ ) (Hellgren 2013). Due to its small size, there is no such boat traffic at the lake that would create noise or waves disturbing the visitors at the beach or swimming area.

We identified the recreation supply and socio-cultural environment of the area by interviewing four city-officials, conducting field visits in the area, and analyzing public documents (environmental and technical reports, detailed landuse plan of the area, website) published by the city of Vantaa. The ecological state of the lake has been thoroughly investigated (University of Helsinki 1993; Särkelä et al. 2008), and the microbiological and chemical water quality of the lake is regularly monitored by the municipal authorities (City of Vantaa 2017b). During the official summer-swimming season (from now on "summer") (15 May - 31 August) the water samples are collected bi-weekly by the city and the amount of intestinal-origin microbes, turbidity and algal blooms are monitored. During the off-summer swimming season (from now on "off-summer") (1 September - 14 May), the water samples are collected every second month.

\section{Recreation demand at Lake Kuusijärvi}

We conducted an on-site survey of visitors to analyze the recreation demand in two seasons (summer and off-summer) using face-to-face semi-structured interviews. We chose onsite interviews to collect data on recreation demands instead of an on-line survey, that could have covered also those people who do not visit the lake area frequently. However, salient socio-cultural values are not necessarily recorded in on-line surveys. Recollections of experiences change already a few weeks after the actual outdoor leisure experience (Lee et al. 1994). Moreover, interviewing visitors and analyzing only direct use and experience values also has some limitations that need to be taken into account. People may hold other sociocultural values they assign to the area that cannot be revealed in on-site studies, but would require other techniques, such as public participation mapping tools, e.g. PPGIS (Ives and Kendal 2013).

We collected the interview data in three separate periods during 2013-2015. Interviews were conducted during weekdays and weekends between 10 am and $6 \mathrm{pm}$. We interviewed altogether 153 people including 99 people in the summer season (seven interview days during 15 June - 31 August 2013) and 54 people in the off-summer season (seven interview days during 5 October 2013-7 May 2014 and two days during 29 November 2014-10 January 2015). The selection of interviewees took place on-site, where randomly selected persons (approximately every fifth in summer, when there are more visitors, and every third in winter, when there are less visitors) in the vicinity of the lake were approached and asked if they would be willing to take part in an interview study. If a couple, a family or a group of visitors were encountered, only one person (adult) of them was interviewed based on the their voluntary interest. 32 interviewees preferred to complete the interview sheet independently. The interviews lasted about $10 \mathrm{~min}$. We used incentives (free coffee or ice-cream) to encourage participation. The response rate was high, as over $80 \%$ of the people we approached participated the interview. Sixty-eight percent of the interviewees were female.

The interview consisted of 12 open questions, one valuation task and a background information query. We asked about the purpose of the visit, how often they visit the lake area during the year, and whether they visit year-round or only in summer or off-summer season, followed by detailed questions about their arrival (e.g. with whom or alone). Then we asked visitors to mention things they enjoy and if there are any disturbing things in the lake area. We allowed the interviewees to freely mention as many things as they wanted and use their own words, because it provides a better way to explore all possible values respondents attach to the place, rather than offering them a fixed list (Scholte et al. 2015). The open questions were followed by a scoring task of the importance of local biophysical units. We asked the interviewees to give a score according to how important different biophysical abiotic elements (clean water, lawn, sandy beach) and biotic elements (natural brooks, surrounding forests, shore vegetation, aquatic nature) are to their positive experience and satisfaction by using the Likert scale from 4 to $10(4-5=$ not important, $6-$ $7=$ somewhat important, $8=$ important, $9-10=$ very important). The values resemble school evaluation scores in Finland, and are generally familiar. Furthermore, we asked background information (age, home city and district, family type, education, occupational status, living type, car ownership, vacation home ownership, water-related hobbies). The language of the interviews was Finnish.

We analyzed the recreation demand from open questions by following the conceptual model (Fig. 1). First we identified and coded all open questions as a binominal variable $(1=$ interviewee mentioned a thing/issue, $0=$ not mentioned by interviewee). We measured a frequency value (proportion of interviewees) for each variable. Then we developed three separate tables for a) use (purpose of visit), b) experience (enjoyed), and c) experience (disturbing). We grouped and classified variables in separate tables into thematic categories based on their characteristics, e.g. "sun-bathing" was grouped under weather and "enjoying peacefulness" was classified under the intangible value. We especially wanted to determine whether demand is (i) directly related to units of supply (abiotic, biotic, features), (ii) social relation, (iii) recreational activity, or (iv) non-measurable intangible characteristics of the area. In the results we present only main thematic categories, 
but all identified and coded variables, together with their frequency values, can be found in Appendix Table 3.

Moreover, frequency values of four scored value classes (4-5 = not important, 6-7 = somewhat important, $8=$ important, 9-10 = very important) were measured. Answers by summer and off-summer visitors were analyzed separately. We used Mann-Whitney U-test to test whether summer and offsummer visitors differed in their socio-demographic characteristics (categorical variable) and scored values. Statistical analyses were performed using SPSS Statistics, version 23.

\section{Results}

\section{Recreation supply at Lake Kuusijärvi}

We identified 14 key elements of recreation supply at Lake Kuusijärvi (Table 1). We divided these into biophysical units (including abiotic and biotic elements) and socio-physical units, according to our conceptual model (Fig. 1), and interpreted the origin of each supply as either artificial, facility, nature-based or service. Seven biophysical elements of supply are provided by local ecosystems (nature-based) and two are artificial in origin (sandy beach and lawn). Two elements are indoor services (café and saunas) with payments, while the use of outdoor facilities is free of charge. Almost all elements of supply are available year round.

The most important local recreation supply is the lake. The ecological condition and aquatic species richness of the lake is fairly good (Särkelä et al. 2008). The fish population and green algae biomass of the lake are normal compared to other similar shallow and humus-rich lakes in Finland (Särkelä et al. 2008). Long-term monitoring of water quality (2003-2013) during the summer indicates that the average variation of the water quality is largely dependent on the number of hotweather days (maximum daily temperature $>25^{\circ} \mathrm{C}$ ), when the number of swimmers increases significantly. Water temperature has been constant during the summer with only little annual variation. The water quality of Lake Kuusijärvi often deteriorates during the summer, being however swimmable throughout the summer, with some exceptions. Comparing changes in water quality during the swimming season in 2013, when summer visitors were interviewed, the amount of Escherichia coli increased clearly during the season, but stayed at the good level $(<1000 \mathrm{mpn} / 100 \mathrm{ml})$. The summer 2013 was exceptionally hot (Finnish Meteorological Institute 2013) and blue algae blooms were common in early June in many inland freshwaters, but not in Lake Kuusijärvi.

There are two brooks flowing into the lake from the catchment area and half of the lake's water comes from groundwater (Särkelä et al. 2008). Water flow is an important function for maintaining water quality. Lake Kuusijärvi is surrounded by forests dominated by Norwegian spruce (Picea abies) mixed with pine (Pinus sylvestris), birches (Betula sp.) and alder (Alnus incata). A recreation trail, which is also accessible for disabled and includes two grilling places, goes around the lake near the waterline and another $1.8 \mathrm{~km}$ recreation trail goes around the lake in the forest a bit further from the waterline. The latter is intended for walkers and runners during the summer and for cross-country skiers during the winter. There are also other recreation trails nearby and good recreation trail connections from the lake area to nearby extensive forest recreation areas, such as Sipoonkorpi National Park to the east. The Outdoor Association of Finland and the City of Vantaa have improved the swimming and sauna facilities at Lake Kuusijärvi during recent decades. For instance, a large playground area has been provided for children by the beach and a lawn area for sunbathers. The sandy beach (150 m long) is artificial and swimming facilities are open year round and during the winter, when the lake is ice-covered, there is an ice-swimming site. Furthermore, regulations and recommendations at the area construct the rules of social behavior. For instance, it is prohibited to drink alcohol and to consume other intoxicating substances at public spaces in urban areas in Finland, although moderate consumption of alcohol is permitted in e.g. picnic parks if it does not cause nuisance to other people (Public Order Act 2003). Since the beginning of 2013, the city of Vantaa banned smoking cigarettes at the Lake Kuusijärvi beach area, although social norms have anyway been rather strict towards smoking (see 3.3.).

\section{Socio-demographic characteristics of summer and off-summer visitors}

The profile of an average interviewee $(n=153)$ was: employed (70.6\%), female (66.7\%), aged 31-45 years old $(35.3 \%)$, with a university or applied university degree (43.8\%), living with a spouse (35.9\%), in an owned (55.6\%) apartment (44.4\%) in the city of Vantaa (58.2\%). This relatively well presents the population of Vantaa, although females, age group 31-45 years old, and persons with a higher education degree and employed are slightly over-presented in the sample. In the city of Vantaa ca. $47 \%$ of the 18-84 years old are females, $22 \%$ are $30-44$ years old, $30 \%$ have a higher education degree and about $60 \%$ of the 18-74 yrs. old and able to work are employed (City of Vantaa 2018). The age distribution of all interviewees ranged from 18 to 85 years (see Appendix Table 3). Only three respondents were born outside Finland.

Comparing socio-demographic characteristics of the interviewed summer and off-summer visitors, we found significant (Mann-Whithey U-test) differences between some variables (Table 2). Summer visitors mostly lived in rented apartments $(47.5 \%)$, a quarter had no car and the majority did not own a vacation home (61.6\%), while the majority of the off-summer visitors lived in an owned (79.6\%) detached 
Table 1 Fourteen elements of local recreation supply, and the origin of the service-providing elements (artificial, facility, nature-based or service)

\begin{tabular}{lllll}
\hline Unit & Element & Origin & Availability & Payments \\
\hline Biophysical (abiotic) & Water & Nature-based & Year round & Free \\
& Sandy beach & Artificial & Non-snow season & Free \\
Biophysical (biotic) & Forests & Nature-based & Year round & Free \\
& Lake & Nature-based & Year round & Free \\
& Two brooks & Nature-based & Year round & Free \\
& Aquatic species & Nature-based & Year round & Free \\
& Shore vegetation & Nature-based & Year round & Free \\
& Wildlife & Nature-based & Year round & Free \\
& Lawn & Artificial & Summer & Free \\
& Three saunas & Service & Year round & Yes \\
& Cafe & Service & Year round & Yes \\
& Swimming jetty & Facility & Year round & Free \\
& Two grilling places & Facility & Year round & Free \\
& Recreation trails & Facility & Year round & Free \\
\hline
\end{tabular}

house $(40.7 \%)$, and owned a car $(88.9 \%)$ and a vacation home $(66.7 \%)$. Single adults without and with children were more common among the summer visitors $(31.1 \%$ and $17.2 \%$, respectively) than among off-summer visitors (13\% and $1.9 \%$, respectively). The summer visitors were more diverse in age range (24.2\% under 30 years) than off-summer visitors, who were mainly older than 46 years $(68.5 \%)$ and only less than $6 \%$ were under 30 years old. In both groups, university or applied university degree (summer visitors $38.4 \%$ and offsummer visitors $53.7 \%$ ) was the most common level of education. However, among summer visitors there were more interviewees with low educational level (only elementary school $14.1 \%$ or high school $17.2 \%$ ) than among offsummer visitors (only elementary school $1.9 \%$ or high school $5.6 \%)$. Students were more common among summer visitors $(6.1 \%)$, while totally absent from the off-summer visitors. All socio-demographic characteristics of summer and off-summer visitors are presented in Appendix Table 3.

\section{Recreation demand at Lake Kuusijärvi}

During the summer, more than one-third (34.3\%), and in offsummer season more than half $(55.5 \%)$ of the interviewees arrived at the lake area with a friend or spouse. However, families with children were more frequent in summer $(36.4 \%)$ than in off-summer $(14.4 \%)$, when a quarter of the interviewees arrived alone $(24.1 \%)$. Whilst the majority $(70.7 \%)$ of the interviewed summer visitors estimated having stayed more than $1.5 \mathrm{~h}$ in the lake area, only $22.2 \%$ of the offsummer visitors planned to stay over $1.5 \mathrm{~h}$. Summer and offsummer visitors also varied in their visiting frequency. Forty point seven percent of the interviewed off-summer visitors, but only $12.1 \%$ of the summer visitors, reported visiting the lake area at least monthly. While $40.4 \%$ of the summer visitors visit the lake area only during the summer, more than $90 \%$ of the off-summer visitors visit the lake area year-round (see Appendix Table 3).

The interviewees mentioned a total of 16 different motivations for their visits (see individual reasons in Appendix Table 4). We grouped the motivations under six different categories: weather (good weather, sunbathing), nature, recreation I (swimming, walking, exercise, hiking and boating, which are mobility-based forms of recreation), recreation II (relaxing and reading, which are sedentary forms of recreation), social relation (social gathering, for children to swim) and facilities or services (sauna, grilling, café) (Fig. 3a). During the summer, weather was an important determinant for visits $(41.4 \%)$, while in the off-summer season it was hardly mentioned $(3.7 \%)$. Summer visitors came to swim $(46.5 \%)$, relax $(30.3 \%)$ and to spend time with friends or family $(29.3 \%)$ or for their children to swim $(30.3 \%)$. Sunbathing and swimming were commonly mentioned together. Parents or grandparents very often spend time relaxing on the beach and at the same time looking after the children. The swimming area was considered as good and safe place for children to swim and play due to a separate swimming area for small children. Off-summer visitors came most often for outdoor recreation $(50.0 \%)$, and for services $(33.4 \%)$.

The interviewees mentioned in total 15 different things they enjoy during their visit (see individual things in Appendix Table 4). We grouped them into nine different categories (Fig. 3b). We consider that things people enjoy are important elements to support positive experiences, and to satisfy their motivation to visit the site (Chan et al. 2011, p. 207). Nature was quite frequently (45.1\%) enjoyed by visitors, but the degree varied among summer (38.4\%) and off-summer visitors $(57.4 \%)$. Summer visitors named specific abiotic elements $(49.5 \%)$ they enjoyed, such as sandy beach or warm swimming water, while off-summer visitors mentioned single abiotic elements less frequently (11.1\%). Those summer 
Table 2 The proportion (\%) of different age groups, dwelling type, housing type, vacation home ownership and car ownership among the interviewed summer ( $n=99)$, off-summer $(n=54)$ visitors and all visitors together $(n=153)$

\begin{tabular}{|c|c|c|c|}
\hline & $\begin{array}{l}\text { Summer } \\
(\mathrm{n}=99)\end{array}$ & $\begin{array}{l}\text { Off-summer } \\
(\mathrm{n}=54)\end{array}$ & $\begin{array}{l}\text { All } \\
(n=153)\end{array}$ \\
\hline \multicolumn{4}{|l|}{ Age group (years old) $* * *$} \\
\hline $18-30$ & 24.2 & 5.6 & 17.6 \\
\hline $31-45$ & 37.4 & 31.5 & 35.3 \\
\hline $46-60$ & 20.2 & 37.0 & 26.1 \\
\hline$>60$ & 17.2 & 25.9 & 20.3 \\
\hline No answer & 1.0 & 0 & 0.7 \\
\hline \multicolumn{4}{|l|}{ Dwelling type ${ }^{* * *}$} \\
\hline Owned & 42.4 & 79.6 & 55.6 \\
\hline Rented & 47.5 & 16.7 & 35.9 \\
\hline Right-of-occupancy & 6.1 & 3.7 & 5.2 \\
\hline No answer & 4.0 & 0 & 3.3 \\
\hline \multicolumn{4}{|l|}{ Housing type** } \\
\hline Apartment & 50.5 & 33.3 & 44.4 \\
\hline Row or terraced house & 27.3 & 24.1 & 26.1 \\
\hline Detached house & 15.2 & 40.7 & 24.2 \\
\hline No answer & 7.1 & 1.9 & 5.2 \\
\hline \multicolumn{4}{|l|}{ Vacation home ${ }^{* * *}$} \\
\hline Not-owning & 61.6 & 33.3 & 51.6 \\
\hline Owning & 36.4 & 66.7 & 47.1 \\
\hline No answer & 2.0 & 0 & 1.3 \\
\hline \multicolumn{4}{|l|}{ Car in the household* } \\
\hline One or several cars & 72.7 & 88.9 & 79.1 \\
\hline No cars & 26.3 & 9.3 & 20.3 \\
\hline No answer & 1.0 & 1.9 & 0.7 \\
\hline
\end{tabular}

Summer interviewees were interviewed during a period of 15 June - 31 August 2013 and winter interviewees during two periods: 5 October 20137 May 2014 and 29 November 2014-10 January 2015. These variables differed significantly (Mann-Whitney U-test). Statistical significance: * $<0.05, * *<0.01, * * *<0.001$

visitors who arrived with children especially enjoyed the "child friendly" beach. Off-summer visitors enjoyed the lake view (i.e. landscape) (13\%) and facilities (46.4\%) much more frequently than summer visitors $(1 \%$ and $17.1 \%$, respectively). Quite many visitors (summer $36.5 \%$, off-summer $48.1 \%$ ) enjoyed recreational activities. Summer visitors enjoyed social relations (e.g. company of a friend or spouse) much more often $(27.3 \%)$ than off-summer visitors $(5.6 \%)$. Atmosphere of the area (e.g. peacefulness) was much more frequently enjoyed by off-summer (14.8\%) than summer $(5.1 \%)$ visitors. However, those interviewees who enjoyed a company of another person or persons never mentioned enjoying peacefulness of the place.

We were also interested in negative experiences of visitors and we asked the interviewees to mention things that disturb them during their visit in the lake area (Fig. 3c). They mentioned a total of 16 different things that disturbed them (see individual disturbing things in Appendix Table 4). The summer and off-summers visitors were very similar with regard to the things they considered most disturbing: social behavior or social relations, i.e. crowding or misbehavior of other visitors, followed by dissatisfaction with the condition of, or lack of, facilities. Some summer visitors complained about loud groups of people drinking alcohol and smoking tobacco at the beach (although not permitted), and some visitors were disturbed especially by the misbehavior of young and foreign people (being too loud). Those visitors who arrived with company less frequently (ca. 10\%) mentioned misbehavior of other visitors as a nuisance than those who arrived alone (ca. 20\%). While summer visitors were disturbed by wild animals (biotic element), off-summer visitors were more sensitive to intangible (e.g. noise) disturbing features.

We asked the interviewees how important different biophysical (abiotic and biotic) elements were for their positive visiting experience (Fig. 4). We also wanted to find out if visitors could identify specific units of ecological systems that are important for delivering ES. Clean water as an abiotic element was most highly valued among all $(n=153)$ interviewed visitors (average score 9.14; SD 1.048). Other scored values significantly differed between summer and off-summer visitors (MannWhitney U-test). Natural brooks (average 7.58; SD 1.73) and water shore vegetation (average 7.58; SD 1.51) evoked the lowest scores among all interviewees. However, the summer and off-summer visitors varied considerably in their responses to natural brooks: $40.0 \%$ of the off-summer visitors gave the highest score (9-10) for brooks, while only $18.2 \%$ of the summer visitors gave brooks the highest score, and $17.2 \%$ of the summer visitors could not even identify brooks $(3.7 \%$ of the off-summer visitors, respectively). Summer visitors, in general, gave lower scores for all these four nature-based provision types, but higher scores for artificial provision types (lawn and sandy beach). Some of the commendations and concerns that the interviewees mentioned in their responses to open questions regarding the lake area and its future are presented as excerpts from the interviews in Appendix Table 5.

\section{Discussion}

\section{Does recreation supply meet demand at Lake Kuusijärvi?}

Many academic experts on ecosystem service (ES) research agree that cultural ecosystem services (CES) is the most challenging ES group to study due to its immaterial, nonconsumptive and indirect value characteristics (e.g. Bryan et al. 2010; Chan et al. 2012; Daniel et al. 2012; Burkhard et al. 2014). It is not easy to define when an ecological system provides CES for people and when CES are a consequence of 
socio-cultural values. In addition, socio-cultural values can emerge from culturally shared beliefs and community values, i.e. socio-cultural environment, and not only from individually held values (Dinnie et al. 2013; Scholte et al. 2015; Vierikko and Niemelä 2016). We aimed to overcome with these challenges by using the conceptual model of CES to study the interactions between recreation supply and demand at urban Lake Kuusijärvi.

Gee and Burkhard (2010) argued that one important aspect of working with CES is to identify those biophysical elements that socio-cultural values are assigned to. We recognized a total of 14 key elements of supply and 22 different socio-cultural values (motivations and source of enjoyment) for recreation demand (Appendix Table 4). Most demands were targeted on tangible elements under the biophysical or socio-physical units. Demands were seasonally dynamic, while recreation supply is rather constant and does not change greatly according to the season.

\section{Whose demand are satisfied by local supply?}

Our results revealed that a far more diverse group of people visits Lake Kuusijärvi in the summer than in the off-summer

a Motivation for a visit (\%)

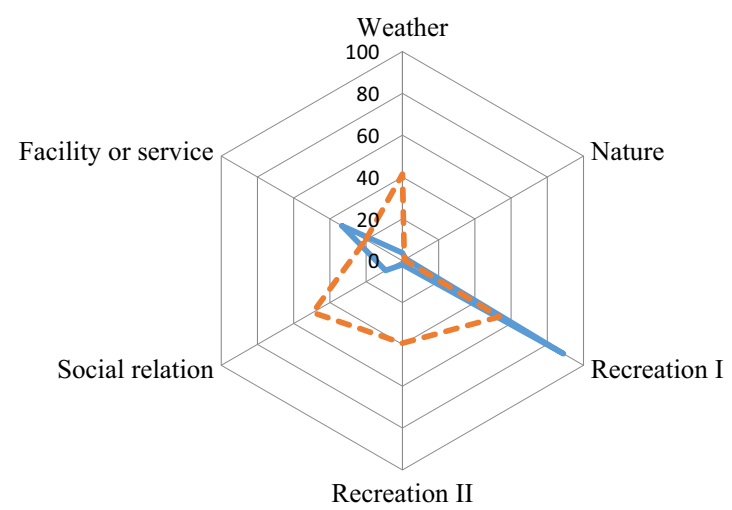

c Negative experiences (\%)

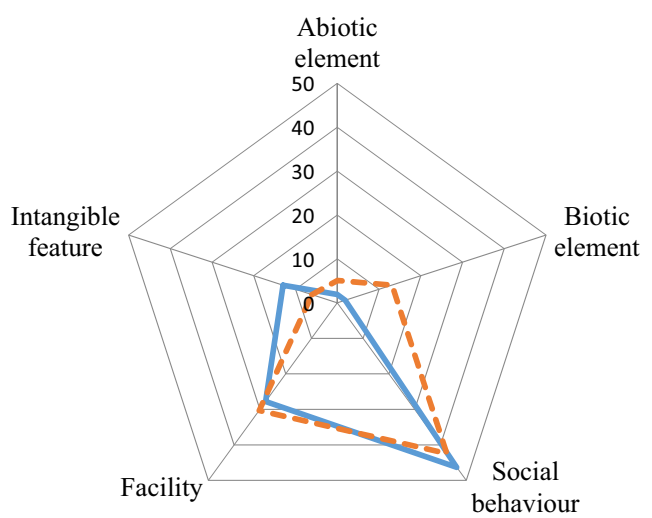

Fig. 3 (a) Six categories of motivations for a visit, (b) nine categories of positive experiences and (c) five categories of negative experiences that were grouped from answers of off-summer (solid line) and summer season (dot line) visitors to the questions i) reason for visit, ii) things they season. Off-summer visitors were a more homogenous group in terms of socio-demographic factors, such as educational level, family type, age and type of living. Young adults and families in particular visited in summer and older people (> $45-\mathrm{y}$ ) in the off-summer season, showing that the area is used by variety of age groups, but in different seasons. However, our finding that most of the off-summer visitors regularly visit the lake area year-round, corroborates previous findings by Pietilä et al. (2015), who studied outdoor recreation in urban green areas in Finland and found that adults aged 25-44 years old used green areas less frequently year-round than older age groups.

Furthermore, we found that most of the summer visitors do not own a vacation home or leisure-time house indicating that the urban lake area is an important place for these people to spend time with their family during the summer season. In Finland, second homes (usually called cottages) are typically located in the countryside in forest environments, often on the shore of a lake or sea, and are dominantly designed for summer time use. Their popularity for leisure time use is important in the Finnish context as about $15 \%$ of households own a second home and about $40 \%$ of Finns have a regular access

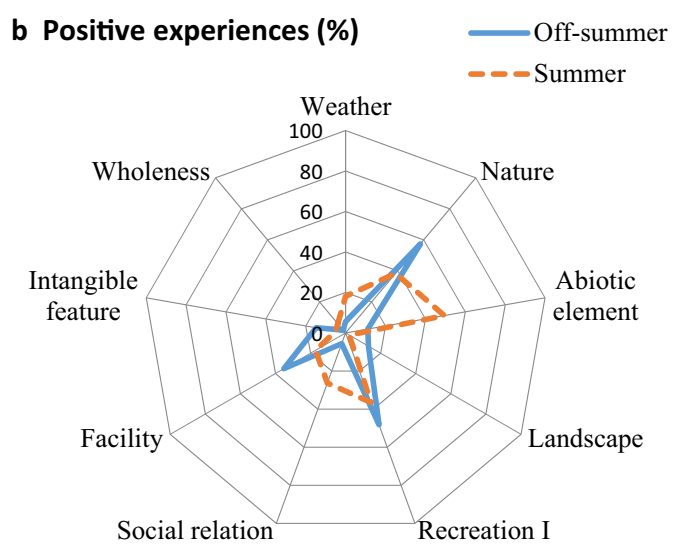

enjoyed and (iii) disturbing things. The figure shows the proportion (\%) of the interviewees who mentioned at least one activity or thing under the value type. The interviewees could mention several reasons or things they experienced 
to a vacation home or leisure-time house, i.e. cottage, since many of them are also used by relatives and friends of the owners (Hiltunen and Rehunen 2014; Adamiak et al. 2017). Moreover, Laatikainen et al. (2015) found that people without a car had a significantly weaker access to urban water areas for recreation. We found that summer visitors owned a car less frequently, indicating that their accessibility to such recreation areas in general is lower than that of off-summer visitors.

The impact of climate change on the delivery of key ecosystem services has been strongly debated in the ES literature and is one of the key focal areas in international and national policies (e.g. Mooney et al. 2009). Nelson et al. (2013) argued that climate change could have a great impact on winter and water-related CES in the United States. Weather is an important determinant of whether people go out and enjoy the supply of CES. Poor weather (rainy, cloudy or cold) influences summer season use more strongly than off-summer season use, because weather was mentioned more frequently as a motivation to visit the lake area in summer. This has a slightly different impact on the demands of different sociodemographic groups. Demands of more versatile visitor groups (e.g. families with children, young adults, visitors without a car) during the summer are more sensitive to weather conditions, and local CES supply cannot substitute the primary reason to visit (good weather, sun-bathing) for almost half of the visitors $(41.4 \%)$. In our study, increase in the number of rainy days decreases CES demand, but would not have a negative influence on CES supply. On the contrary, longterm warm periods increase the water-dependent demand for CES and can decrease water quality and the supply of water- dependent CES. Negative changes in water quality (bluegreen algal blooms, increase in coliform bacteria) can cause temporal closing of the swimming area.

\section{Seasonality of socio-cultural values at Lake Kuusijärvi}

We were especially interested in whether there are differences in socio-cultural values between summer and off-summer visitors in the urban lake area. It is not a surprise that the amount of visitors increases in the summer, which is the "hot season" for outdoor leisure activities in Finland. Although we did not have systematically collected visitor number data available from different seasons, we visually observed the number of visitors and cars parked in the area during the interview days. Based on our observations and a report by the City of Vantaa (2016), the lack of parking places is a considerable problem especially in summer season, but less so in off-summer season (except if there is an organized event at the lake area). This and our own visual estimations of visitor numbers indicate that there are considerably more visitors at the lake area during summer season than off-summer season.

Summer visitors tended to have more reasons to visit the site, but they mentioned fewer things they enjoyed than offsummer visitors. An interesting finding was that immaterial socio-cultural values, e.g. enjoying peacefulness, were more frequently mentioned by the off-summer than summer visitors. During hot summer days the beach area was always very crowded, full of swimmers and sunbathers. The dense crowd of visitors at the lake obviously has consequences for supply: the socio-cultural environment of the area is lively and full and

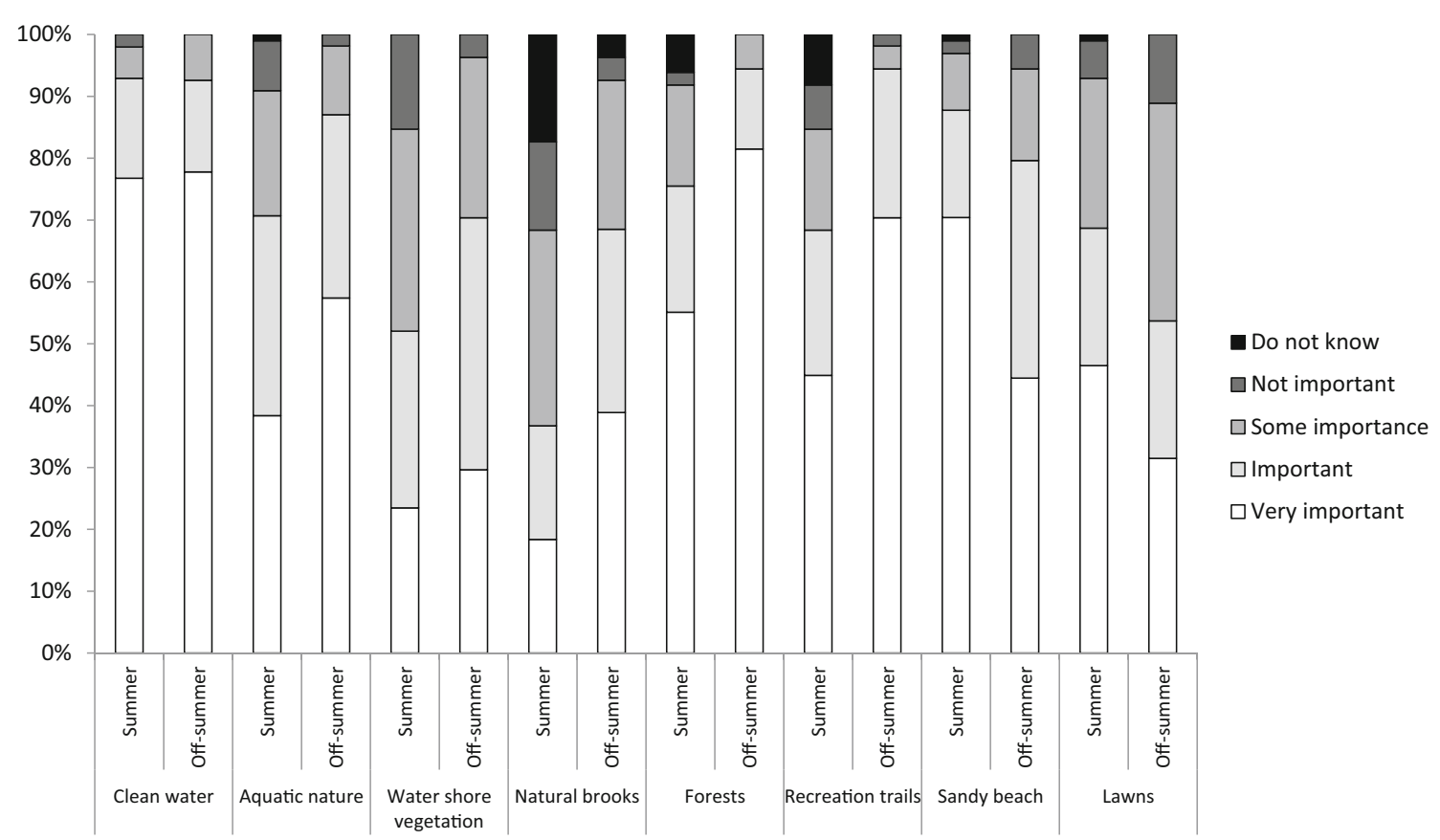

Fig. 4 Scored values for eight biophysical elements given by summer and off-summer visitors. The figure shows the proportion (\%) of the interviewees who valued each element in the following categories: very important, important, some importance, not important and do not know 
it may cause a decrease in demand among certain visitors who e.g. enjoy peacefulness and perhaps have a better access to a summer cottage in the countryside.

While the main motivation of off-summer visitors to visit the area is active recreation, summer visitors tend to be more diverse in their reasons to arrive. Off-summer visitors, who commonly visit to walk around the lake and for sauna or café services, enjoy nature and value most facilities. Furthermore, biotic elements, such as forest or natural brooks, are more important for positive visiting experience for off-summer visitors than for summer visitors, who tend to stay close to the swimming area and enjoy and value abiotic features, such as the sandy beach. Summer visitors also enjoy social gathering more often than off-summer visitors, who prefer to visit the lake area alone or with a friend.

Nature is highly enjoyed and valued by visitors in both seasons, although nature was not the main motivation to visit Lake Kuusijärvi. However, summer visitors value specific biotic elements less than off-summer visitors. Sandy beach and lawn that are directly used by summer visitors, are more important to them than natural biotopes (e.g. brooks or shore vegetation), indicating these elements of the ecological system have no meaning for them when they enjoy or value nature. "Meaning" in this case refers to subjects or features that are important when an individual enjoys or values nature (Brown 1984). Some biotic elements can even be perceived as disservices (Lyytimäki and Sipilä 2009). Almost a quarter of the summer visitors felt that wild animals disturb them. Off-summer visitors, on the contrary, more often valued specific biotic elements with high scores than summer visitors, indicating that offsummer visitors are more aware of local urban biodiversity, and it is important for their positive visiting experiences. Why is nature valued by most visitors, even though specific biotic features are not acknowledged? We argue that nature is an inherent value of the Lake Kuusijärvi area for all visitors and they enjoy nature as a whole, regardless of the reason to visit or if specific biotic features are not acknowledged.

Degree of involvement (visiting frequency) seems to have an impact on how visitors value biophysical features. Offsummer visitors visit the area more regularly than summer visitors, and many of them visit only occasionally during the summer. Seventeen percent of the interviewed summer visitors did not know about the natural brooks flowing into the lake and many of them assigned them a low value, whereas off-summer visitors are more aware of the brooks.

Facilities and services are enjoyed and valued year round. Outdoor facilities can support positive experiences and satisfy visitor's needs, though poor condition or lack of facilities can decrease visitor satisfaction, which was revealed when we asked about the things that disturbed the visitors. Previous studies have shown that visitors highly value such facilities and features as grilling places and children's playgrounds that support social gathering (McCormack et al. 2010) in urban green environment.

Summer and off-summer visitors were both quite often disturbed by crowding and behavior of others at the lake area. However, crowding was a decisive reason not to visit during the "hot season" for off-summer visitors as they often mentioned during the interview, while summer visitors tend to cope with crowding (Budruk et al. 2008). Crowding is defined as a "negative evaluation of a certain density or number of encounters" (Shelby et al. 1989). It is a question of perceived levels of crowding, rather than real increase in the number of visitors that can reduce the quality of the visiting experiences (Shelby et al. 1989; Kakoyannis and Stankey 2002). Moreover, crowding can increase the frequency of events causing negative experiences, for instance perceived misbehavior of other visitors. Depending if social norms and demands towards acceptable or desired social behavior are effective, they can contribute to inclusive or welcoming atmosphere of the recreation site.

\section{Conclusions}

Our study, in which we analyzed direct links between recreation supply and demand related to an urban lake ecosystem by adopting comprehensive ES approach, is novel in the research field. Our results suggest that the supply of recreation at Lake Kuusijärvi was surprisingly similar between the summer and off-summer seasons, although recreation demand changed substantially seasonally. We found that biophysical and socio-physical elements can directly support most demands, but some are intangible. We also noticed that socio-cultural environment could be controlled at certain level (e.g. safe environment for children), but is strongly influenced by experiences of the visitors at the recreation site. Intangible CES, such as peacefulness of the site, need careful attention because they are most vulnerable, and will be threatened if the volume of demand increases. We argue that there is a potential tradeoff between the quantity (amount of visitors) and perceived quality (experience values) of CES demand. Some sociocultural values, such as peacefulness, will be lost if there is too much demand for the place. Taking seasonal variation of demands into account in planning and management is an important factor in supporting local CES year-round.

Acknowledgements Open access funding was provided by the University of Helsinki. The study was funded by the Academy of Finland AKVA programme's project 'Environmental Justice and Ecosystem Services: Access, equity and participation in the use and management of aquatic environments in the Helsinki region' (ENJUSTESS), 2012-2016 (the Academy of Finland grant number 263403), and the project 'Green Infrastructure and Urban Biodiversity for Sustainable Urban Development and the Green Economy' (GREEN SURGE), EU FP7 collaborative project (FP7-ENV.2013.6.2-5-603567). We thank Stephen Venn for language checking and useful comments. 


\section{Appendix 1}

Table 3 Background statistics of the interviewed summer $(n=99)$, off-summer visitors $(n=54)$ and all visitors together $(n=153)$. Values are proportion (\%) of respondents

\begin{tabular}{|c|c|c|c|}
\hline & Summer $(\mathrm{n}=99)$ & $\begin{array}{l}\text { Off- } \\
\text { summer }(n=54)\end{array}$ & All $(n=153)$ \\
\hline \multicolumn{4}{|l|}{ Home town } \\
\hline Vantaa & 57.6 & 59.3 & 58.2 \\
\hline Helsinki & 26.3 & 25.9 & 26.1 \\
\hline Kerava & 3.0 & 7.4 & 4.6 \\
\hline Espoo & 2.0 & 5.6 & 3.3 \\
\hline Sipoo & 1.0 & 1.9 & 1.3 \\
\hline Other & 7.1 & 0 & 4.6 \\
\hline No answer & 3.0 & 0 & 2.0 \\
\hline \multicolumn{4}{|l|}{ Arrived with } \\
\hline Family including children & 36.4 & 14.8 & 28.8 \\
\hline A spouse or friend & 34.3 & 55.6 & 41.8 \\
\hline Alone & 15.2 & 24.1 & 18.3 \\
\hline Group & 12.1 & 5.6 & 9.8 \\
\hline No answer & 2.0 & 0 & 1.3 \\
\hline \multicolumn{4}{|l|}{ Arrived by } \\
\hline Car & 71.7 & 81.5 & 75.2 \\
\hline Bicycle & 16.2 & 0 & 10.5 \\
\hline Public transportation & 10.1 & 0 & 6.5 \\
\hline Walking & 1.0 & 16.7 & 6.5 \\
\hline Motorcycle & 1.0 & 1.9 & 1.3 \\
\hline No answer & 0 & 0 & 0 \\
\hline Travel distance $(\mathrm{km})$ (median) & 8.2 & 8.7 & 8.3 \\
\hline \multicolumn{4}{|l|}{ Estimated duration of stay } \\
\hline$<30 \min$ & 5.1 & 20.4 & 10.5 \\
\hline $30-90 \mathrm{~min}$ & 19.2 & 57.4 & 32.7 \\
\hline $1.5-3 \mathrm{~h}$ & 50.5 & 22.2 & 40.5 \\
\hline $3-5 \mathrm{~h}$ & 20.2 & 0 & 13.1 \\
\hline$>5 \mathrm{~h}$ or whole day & 4.0 & 0 & 2.6 \\
\hline No answer & 1.0 & 0 & 0.7 \\
\hline \multicolumn{4}{|l|}{ Visiting frequency } \\
\hline Does not visit in other seasons & 42.4 & 7.4 & 30.1 \\
\hline Occasionally & 27.3 & 14.8 & 22.9 \\
\hline $1-4$ times a year & 13.1 & 18.5 & 15.0 \\
\hline $1-2$ times a month & 3.0 & 22.2 & 9.8 \\
\hline Once a week & 9.1 & 18.5 & 12.4 \\
\hline Several times a week & 0 & 11.1 & 3.9 \\
\hline Daily & 0 & 7.4 & 2.6 \\
\hline No answer & 5.1 & 0 & 3.3 \\
\hline
\end{tabular}




\section{Appendix 2}

Table 4 Proportion (\%) of different motivations to visit, different things visitors enjoy (experience value), and disturbing things, the interviewed visitors in summer $(n=99)$, off-summer $(n=54)$ and all visitors together $(n=153)$, mentioned

\begin{tabular}{|c|c|c|c|c|}
\hline Motivation category & Reason for visit & $\begin{array}{l}\text { Summer } \\
(\mathrm{n}=99)\end{array}$ & $\begin{array}{l}\text { Off-summer } \\
(\mathrm{n}=54)\end{array}$ & $\begin{array}{l}\text { All } \\
(n=153)\end{array}$ \\
\hline \multirow[t]{2}{*}{ Weather } & Sun bathing & 35.4 & 0 & 22.9 \\
\hline & Good weather & 8.1 & 3.7 & 6.5 \\
\hline Nature & Nature & 1.0 & 1.9 & 1.3 \\
\hline \multirow[t]{6}{*}{ Recreation I (Mobility-based) } & Swimming & 46.5 & 24.1 & 38.6 \\
\hline & Walking & 4.0 & 22.2 & 10.5 \\
\hline & Outdoor life & 4.0 & 50.0 & 20.3 \\
\hline & Exercising & 5.1 & 11.1 & 7.2 \\
\hline & Hiking & 2.0 & 7.4 & 3.9 \\
\hline & Boating & 1.0 & 0 & 0.7 \\
\hline \multirow[t]{2}{*}{ Recreation II (Sedentary) } & Relaxing & 30.3 & 1.9 & 26.1 \\
\hline & Reading & 25.3 & 0 & 16.3 \\
\hline \multirow[t]{2}{*}{ Social relation } & For children to swim & 26.3 & 0 & 17.0 \\
\hline & Social gathering & 29.3 & 9.3 & 22.2 \\
\hline \multirow[t]{3}{*}{ Facility or service } & Cafe & 13.1 & 20.4 & 14.4 \\
\hline & Grilling & 7.1 & 5.6 & 6.5 \\
\hline & Sauna & 0 & 13.0 & 4.6 \\
\hline Positive experience & Source of demand & $\begin{array}{l}\text { Summer } \\
(\mathrm{n}=99)\end{array}$ & $\begin{array}{l}\text { Off-summer } \\
(\mathrm{n}=54)\end{array}$ & $\begin{array}{l}\text { All } \\
(n=153)\end{array}$ \\
\hline Weather & Sun & 1.2 & 5.6 & 13.7 \\
\hline Nature & Nature & 38.4 & 57.4 & 45.1 \\
\hline \multirow[t]{2}{*}{ Abiotic element } & Sandy beach & 34.3 & 3.7 & 23.5 \\
\hline & Warm swimming water & 29.3 & 9.3 & 22.2 \\
\hline Landscape & Lake view & 1.0 & 13.0 & 5.2 \\
\hline \multirow[t]{2}{*}{ Recreation I (mobility-based) } & Swimming & 27.3 & 25.9 & 26.8 \\
\hline & Outdoor life & 10.1 & 31.5 & 17.6 \\
\hline Social relation & Social gathering & 27.3 & 5.6 & 19.6 \\
\hline \multirow[t]{5}{*}{ Facility or service } & Trails & 0 & 9.3 & 3.3 \\
\hline & Grilling place & 2.0 & 9.3 & 4.6 \\
\hline & Sauna & 2.0 & 14.8 & 6.5 \\
\hline & Cafe & 11.1 & 7.4 & 9.8 \\
\hline & Children's playground & 2.0 & 5.6 & 3.3 \\
\hline Intangible feature & Peacefulness & 5.1 & 14.8 & 8.5 \\
\hline \multirow[t]{2}{*}{ Wholeness } & The whole area & 6.1 & 1.9 & 4.6 \\
\hline & Other & 1.0 & 14.8 & 5.9 \\
\hline Disturbance category & Disturbing factor & $\begin{array}{l}\text { Summer } \\
(\mathrm{n}=99)\end{array}$ & $\begin{array}{l}\text { Off-summer } \\
(\mathrm{n}=54)\end{array}$ & $\begin{array}{l}\text { All } \\
(n=153)\end{array}$ \\
\hline Biotic element & Wildlife & 13.1 & 1.9 & 9.2 \\
\hline \multirow[t]{2}{*}{ Abiotic element } & Condition of the beach & 1.0 & 0 & 0.7 \\
\hline & Water quality of the lake & 5.1 & 1.9 & 3.9 \\
\hline \multirow[t]{3}{*}{ Social behavior } & Crowding & 22.2 & 29.6 & 24.8 \\
\hline & Trashes & 19.2 & 18.5 & 19.0 \\
\hline & Misbehavior of others & 13.1 & 14.8 & 13.7 \\
\hline Facility or service or lack of them & Shortage of parking places & 10.1 & 5.6 & 8.5 \\
\hline
\end{tabular}


Table 4 (continued)

\begin{tabular}{|c|c|c|c|c|}
\hline & Condition of grilling sites & 6.1 & 7.4 & 6.5 \\
\hline & Condition of clothing huts & 6.1 & 7.4 & 6.5 \\
\hline & Cafe services & 6.1 & 5.6 & 5.9 \\
\hline & Lack of guidance signs & 4.0 & 7.4 & 5.2 \\
\hline & Lack of outdoor benches & 2.0 & 1.9 & 2.0 \\
\hline & Condition of saunas & 1.0 & 5.6 & 2.6 \\
\hline & Lack of outdoor showers & 1.0 & 1.9 & 1.3 \\
\hline & Ongoing renovations & 0 & 13.0 & 4.6 \\
\hline Intangible feature & Noise (including traffic noise) & 6.1 & 13.0 & 8.5 \\
\hline
\end{tabular}

\section{Appendix 3}

Table 5 Excerpts from the interviews depicting some of the commendations and concerns that the interviewees mentioned regarding the lake area and its future. The excerpts are translations from the original answers in Finnish

A "There is nice and relaxed atmosphere here, surrounding nature is good, and there is something for everyone here. I don't think the services need to be to a T. However, birds and gulls bother me."

B "I enjoy swimming here and as the "dock-fenced" swimming area for small children is safe, there's no need to panic all the time."

C "Kids love this place, the food is good and it's close to where we live. It think there are many things to do here, kind of something for everybody. I hope they don't make the environment too modern here in the future, but preserve the surrounding natural vegetation."

D "I come here early in the morning when there are few people here. I really like the whole area, environment and nature - and the docks are good!"

E "This is a nice place to swim and the sandy beach and grilling sites are great."

F "As a whole, this is a vital place for someone like me who lives in an apartment building with no green areas nearby."

G "I hope that nature surrounding the lake would remain as nice as it is. I think there is too much litter in the area."

$\mathrm{H} \quad$ "I have my doubts if the natural lake such as this will in the long run sustain the huge number of people visiting here. It has been sometimes so full here that I don't know where to put my feet on."

I "I generally like it very much here, but sometimes the behaviour of foreigners is disturbing, they don't know how to behave here. Also, some people feed the ducks and they become tame. People should be educated that they should not feed them."

J "I am worried how to fit in here in the future as this is so popular place and there are so many people here - and where to park?"

K "There could be more bathing huts and it would be nice if they had floors. Also, there should be more benches for elderly people to sit on."

L "I'm concerned on sunbathing space as there will certainly be more and more visitors here in the future. Water is too cold for me to swim."

M "During really warm and sunny days the beach can be so packed that there is now space to fit in. There has been a bad smell in the bathing huts sometimes."

N "I am concerned on the degradation of water quality of the lake, increasing rubbish and overall the sufficiency of space here. Public transportation to here should be improved." 
Open Access This article is distributed under the terms of the Creative Commons Attribution 4.0 International License (http:// creativecommons.org/licenses/by/4.0/), which permits unrestricted use, distribution, and reproduction in any medium, provided you give appropriate credit to the original author(s) and the source, provide a link to the Creative Commons license, and indicate if changes were made.

\section{References}

Adamiak C, Pitkänen K, Lehtonen O (2017) Seasonal residence and counterurbanization: the role of second homes in population redistribution in Finland. GeoJournal 82:1035-1050

Bell S, Simpson M, Tyrväinen L, Sievänen T, Pröbstl U (2009) European Forest recreation and tourism. Taylor \& Francis, A Handbook

Brown TC (1984) The concept of value in resource allocation. Land Econ 60:231-246

Bryan BA, Raymond CM, Crossman ND, Macdonald DH (2010) Targeting the management of ecosystem services based on social values: where, what, and how? Landsc Urban Plan 97:111-122

Buckley R (2005) Recreation ecology research effort: an international comparison. Tour Recreat Res 30:99-101

Budruk M, Wilhem Stanis SA, Schneider IE, Heisey JJ (2008) Crowding and experience-use history: a study of the moderating effect of place attachment among water-based recreationists. Environ Manag 41: $528-537$

Burkhard B, Kandziora M, Hou Y, Müller F (2014) Ecosystem service potentials, flows and demand - concepts for spatial localisation, indication and quantification. Landscape Online 34:1-32

Chan KMA, Goldstein J, Satterfield T, Hannahs N, Kikiloi K, Naidoo R, Vadeboncoeur N, Woodside U (2011) Cultural services and non-use values. In: Kareiva P, Tallis H, Ricketts TH, daily GC, Polasky S (eds) natural capital: theory and practice of mapping ecosystem services. Oxford University press. Pp 206-228

Chan KMA, Guerry AD, Balvanera P, Klain S, Satterfield T, Basurto X, Bostrom A, Chuenpagdee R, Gould R, Halpern BS, Hannahs N, Levine J, Norton B, Ruckershaus M, Russell R, Tam J, Woodside U (2012) Where are cultural and social in ecosystem services? A framework for constructive engagement. BioScience 62:744-756

Chiesura A (2004) The role of urban parks for the sustainable city. Landsc Urban Plan 68:129-138

CICES (2017) The Common International Classification of Ecosystem Services (CICES). http://cices.eu/. Accessed 8 June 2017

City of Vantaa (2016) Kuusijärvi Sipoonkorven portiksi - Kuusijärven kehittämissuunnitelma. 091400 Kuusijärvi-Sipoonkorpi -selvitys. Vantaan kaupunki, Kaupunkisuunnittelu, Kuusijärvityöryhmä 9.5.2016. [in Finnish]. https://www.vantaa.fi/instancedata/prime_ product_julkaisu/vantaa/embeds/vantaawwwstructure/124453 kaupsu_kuusujarvi.pdf. Accessed 23 November 2018

City of Vantaa (2017a) Tietoa Vantaasta (Information about the city of Vantaa) [in Finnish]. http://www.vantaa.fi/tietoa_vantaasta. Accessed 8 June 2017

City of Vantaa (2017b) Uimavesien laadunvalvonta (Monitoring the quality of swimming waters) [in Finnish]. http://www.vantaa.fi/ asuminen_ja_ymparisto/ymparisto-_ja_elainterveys/ terveydensuojelu/uimavesivalvonta. Accessed 8 June 2017

City of Vantaa (2018) Tietoa Vantaan väestöstä [in Finnish]. http://www. vantaa.fi/hallinto_ja_talous/tietoa_vantaasta/tilastot_ja tutkimukset/vaesto_ja_ennuste. Accessed 24 November 2018

Curtis J, Stanley B (2016) Water quality and recreational angling demand in Ireland. J Outdoor Recreation Tour 14:27-34

Dallimer M, Irvine KN, Skinner AMJ, Davies ZG, Rouquette JR, Maltby LL, Warren PH, Armsworth PR, Gaston KJ (2012) Biodiversity and the feel-good factor: understanding associations between selfreported human well-being and species richness. BioScience 62: $47-55$

Daniel T, Muhar A, Arnberger A, Aznar O, Boyd JW, Chan KMA, Costanza R, Elmqvist T, Flint CG, Gobster PH, Grêt-Regamey A, Lave R, Muhar S, Penker M, Ribe RG, Schauppenlehner T, Sikor T, Soloviy I, Spierenburg M, Taczanowska K, Tam J, von der Dunk A (2012) Contributions of cultural services to ecosystem services agenda. PNAS 109:8812-8819

D'Antonio A, Monz C, Newman P, Lawson S, Taff D (2013) Enhancing the utility of visitor impact assessment in parks and protected areas: a combined socio-ecological approach. J Environ Manag 124:72-81

D'Antonio A, Monz C, Larson N, Rohman A (2016) An application of recreation resource assessment techniques to inform management action in an urban-proximate natural area. J Outdoor Recreation Tour 14:12-21

Dinnie E, Brown KM, Morris S (2013) Community, cooperation and conflict: negotiating the social well-being benefits of urban greenspace experiences. Landsc Urban Plan 112:1-9

Doherty E, Murphy G, Hynes S, Buckley C (2014) Valuing ecosystem services across water bodies: results from a discrete choice experiment. Ecosyst Serv 7:89-97

Felipe-Lucia MR, Comín FA, Escalera-Reyes J (2014) A framework for the social valuation of ecosystem services. Ambio 44:308-318

Finnish Meteorological Institute (2013) Kesän 2013 sää (Weather in summer 2013). http://ilmatieteenlaitos.fi/kesa-2013. Accessed 6 June 2017. [in Finnish]

Gee K, Burkhard B (2010) Cultural ecosystem services in the context of offshore wind farming: a case study from the west coast of Schleswig-Holstein. Ecol Complex 7:349-358

Gledhill DG, James P (2012) Socio-economic variables as indicators of pond conservation value in an urban landscape. Urban Ecosyst 15: 849-861

Goddard W, Melville S (2004) Research methodology: an introduction, 2nd edn. Publishing, Blackwell

Haines-Young R, Potschin M (2010) The links between biodiversity, ecosystem services and human well-being. In: Raffaelli DG, Frid CLJ (eds) ecosystem ecology: a new synthesis. Cambridge University press, pp 110-139

Hamberg L, Malmivaara-Lämsä M, Lehvävirta S, O’Hara RB, Kotze DJ (2010) Quantifying the effects of trampling and habitat edges on forest understory vegetation - a field experiment. J Environ Manag 91:1811-1820

Hauru K, Koskinen S, Kotze DJ, Lehvävirta S (2014) The effects of decaying logs on the aesthetic experience and acceptability of urban forests - implications for forest management. Landsc Urban Plan 123:114-123

Hellgren U (2013) Kuusijärven uimavesiprofiili (Swimming water profile of Lake Kuusijärvi). Vantaan kaupunki, Maankäyttö ja ympäristö [in Finnish] http://www.vantaa.fi/instancedata/prime_product julkaisu/ vantaa/embeds/vantaawwwstructure/108193_Kuusijarven uimavesiprofiili_11.4.pdf. Accessed 8 June 2017

Hiltunen MJ, Rehunen A (2014) Second home mobility in Finland: patterns, practices and relations of leisure oriented mobile lifestyle. Fennia 192:1-22

Ives CD, Kendal D (2013) Values and attitudes of the urban public towards peri-urban agricultural land. Land Use Policy 34:80-90

Kakoyannis C, Stankey GH (2002) Assessing and evaluating recreational uses of water resources: implications for an integrated management framework. General technical report PNW-GTR-536, USDA Forest Service, Pacific northwest Research Station

Korpela KM, Ylén M, Tyrväinen L, Silvennoinen H (2010) Favorite green, waterside and urban environments, restorative experiences and perceived health in Finland. Health Promot Int 25:200-209 
Laatikainen T, Tenkanen H, Kyttä M, Toivonen T (2015) Comparing conventional and PPGIS approaches in measuring quality of access to urban aquatic environments. Landsc Urban Plan 144:22-33

Laukkanen JA, Laukkanen T, Kunutsor SK (2018) Cardiovascular and other health benefits of sauna bathing: a review of the evidence. Mayo Clin Proc 93:1111-1121

Lee Y, Dattilo J, Howard D (1994) The complex and dynamic nature of leisure experience. J Leis Res 26:195-211

Lyytimäki J, Sipilä M (2009) Hopping on one leg - the challenge of ecosystem disservices for urban green management. Urban For Urban Greening 8:309-315

MacKay KJ, Campbell JM (2004) A mixed-method approach for measuring environmental impacts in nature-based tourism and outdoor recreation settings. Tour Anal 9:141-152

Marttila H (2007) Helsingin lammet (ponds in Helsinki). Publications by the City of Helsinki environment Centre 2/2007. [in Finnish with an abstract in English]

McCormack GR, Rock M, Toohey AM, Hignell D (2010) Characteristics of urban parks associated with park use and physical activity: a review of qualitative research. Health Place 16:712-726

McIntyre N, Moore J, Yuan M (2008) A place-based, values-centered approach to managing recreation on Canadian crown lands. Soc Nat Resour 21:657-670

MEA (Millennium Ecosystem Assessment) (2005) Ecosystems and human well-being: biodiversity synthesis. World Resources Institute, Washington, DC

Mooney H, Larigauderie A, Cesario M, Elmqvist T, Hoegh-Guldberg O, Lavorel S, Mace GM, Palmer M, Scholes R, Yahara T (2009) Biodiversity, climate change, and ecosystem services. Curr Opin Environ Sustain 1:46-54

Nelson EJ, Kareiva P, Ruckelshaus M, Arkema K, Geller G, Girvetz E, Goodrich D, Matzek V, Pisnky M, Reid W, Saunders M, Semmens D, Tallis H (2013) Climate change's impact on key ecosystem services and the human well-being they support in the US. Front Ecol Environ 11:483-493

Ormsby J, Moscardo G, Pearce P, Foxlee J (2004) A review of research into tourist and recreational uses of protected natural areas. Research publication series no. 79, great barrier reef Marine Park authority

Pietilä M, Neuvonen M, Borodulin K, Korpela K, Sievänen T, Tyrväinen L (2015) Relationships between exposure to urban green spaces, physical activity and self-rated health. J Outdoor Recreation Tour 10:44-54

Plieninger T, Dijks S, Oteros-Rozas E, Bieling C (2013) Assessing, mapping, and quantifying cultural ecosystem services at community level. Land Use Policy 33:118-129
Public Order Act (2003) Finland's public order Act. Ministry of the Interior, Finland. https:/www.finlex.fi/fi/laki/kaannokset/2003/ en20030612_20100774.pdf. Accessed 25 November 2018

Rall E, Bieling C, Zytynska S, Haase D (2017) Exploring city-wide patterns of cultural ecosystem service peceptions and use. Ecol Indic 77:80-95

Raymond CM, Bryan BA, MacDonald DH, Cast A, Strathearn S, Grandgirard A, Kalivas T (2009) Mapping community values for natural capital and ecosystem services. Ecol Econ 68:1301-1315

Särkelä A, Lahti K, Männynsalo J (2008) Kuusijärven tila vuonna 2007 (State of Lake Kuusijärvi in 2007). Vantaan kaupunki, ympäristökeskus C6:2008 [in Finnish]

Scholte SSK, van Teeffelen AJA, Verburg PH (2015) Integrating sociocultural perspectives into ecosystem services valuation: a review of concepts and methods. Ecol Econ 114:67-78

Shelby B, Vaske JJ, Heberlein TA (1989) Comparative analysis of crowding in multiple locations: results from fifteen years of research. Leis Sci 11:269-291

Sievänen T, Neuvonen M (eds) (2011) Luonnon virkistyskäyttö 2010 (Recreration use of nature 2010). Working Papers of the Finnish Forest Research Institute 212. [in Finnish]

TEEB (The Economics of Ecosystems and Biodiversity) (2011) TEEB Manual for Cities: Ecosystem Services in Urban Management. www.teebweb.org. Accessed 8 June 2017

University of Helsinki (1993) Selvitys Vantaan Kuusijärven planktonista, kalastosta ja sedimentistä kesällä 1992 (Study of plankton, fish population and sediment of Lake Kuusijärvi in Vantaa in summer 1992). Helsingin yliopisto, Limnologian ja ympäristönsuojelun laitos/ limnologia C8:1993 [in Finnish]

Vesterinen J, Pouta E, Huhtala A, Neuvonen M (2010) Impacts of changes in water quality on recreation behavior and benefits in Finland. J Environ Manag 91:984-994

Vierikko K, Niemelä J (2016) Bottom-up thinking - identifying sociocultural values of ecosystem services in local blue-green infrastructure planning in Helsinki, Finland. Land Use Policy 50:537-547

Voigt A, Wurster D (2015) Does diversity matter? The experience of urban nature's diversity: case study and cultural concept. Ecosyst Serv 12:200-208

Völker S, Kistemann T (2013) "I'm always entirely happy when I'm here!" urban blue enhancing human health and well-being in Cologne and Düsseldorf, Germany. Soc Sci Med 78:113-124

Yli-Pelkonen V (2013) Importance of recreational ecosystem services in Helsinki, Finland. Manag Environ Qual Int J 24:365-382

Yli-Pelkonen V, Pispa K, Helle I (2006) The role of stream ecosystems in urban planning: a case study from the stream Rekolanoja in Finland. Manag Environ Qual Int J 17:673-688 